\title{
覀性腫瘍の脊椎転移例に対する手術的治療の検討
}

\author{
福岡市民病院整形外科 \\ 宏 洲 士 郎・黒 瀬 真之輔 \\ 小山正信・甲 斐之尋 \\ 中 島 康 晴·前 隆 男
}

\section{Clinical Research of Surgical Treatment for Metastatic Spinal Tumors \\ by}

Shirou Hiroshima, Shinnosuke Kurose, Masanobu Oyama, Yukihiro Kai, Yasuharu Nakashima and Takao Mae

Department of Orthopaedic Surgery,

Fukuoka City Hospital, Fukuoka, Japan

From May 1989 to May 1992, twenty patients were surgically treated for metastatic spinal tumors. Metastasis was from primary lesions of the breast in seven cases, kidney in four cases, liver in three cases, digestive tract in two cases and others in four cases. Nineteen cases had pain and 16 cases showed neurologic deficits. Two cases were treated by posterior fixation, ten cases by posterior fixation and decompression, and 12 cases by a combined anterior and posterior procedure.

As a result, all cases had pain relief, and neurological improvement was obtained in seven cases. Ten cases (breast: six, kidney: three, other: one) survived, while the remaining ten cases died. If the primary lesion is one of low malignancy, surgical treatment is recommended because of the improvement of QOL and life expectancy.

Key words: Metastatic spinal tumor (転移性脊椎腫湯), surgical indication (手術適応), surgical treatment (手術的治療方法)

\section{はじめに}

近年, 診断法, 治療法の発達により, 悪性腫瘍の延 命率が上昇している，それに伴い，整形外科領域にお いては，骨転移を有する症例に遭遇する機会が増えて いる．その中でも最標的部位の一つである脊椎骨転移 は, 頑固な疼痛, 脊髄 (馬尾) 症状の発現或は発生す る危険性があり, 余命の限られた患者の精神的肉体的 苦痛, $\mathrm{ADL}, \mathrm{QOL}$ の低下を来してくる.こういう例 に対して, 我々は，1）疼痛の改善或は除去 2 ）春 䯣（馬尾）症状の改善或は発生予防 3 ) 脊椎構築上 の不安定性の改善 4) QOL の向上を目的として, 手 術療法を行っている.
対

象

対象は, 1989 年 5 月より 1993 年 5 月まで当科にて 手術を行った 20 例（男性 11 例，女性 9 例）で, 年齢 は 33〜65 歳 (平均 51 歳) であった。

転移レベルは, 頚椎 3 例, 胸椎 14 例, 腰椎 7 例 （重複例を含む）であり，そのうち 1 椎に限局したも の 13 例， 2 椎にわたったもの 3 例，3椎以上にわたっ たもの 4 例であった.

原発巣は, 乳腺 7 例, 腎臓 4 例, 肝・胆道系 3 例, 消化器系 2 例, 前立腺 1 例, リンパ系 2 例, 骨髄 1 例 であった，そのうち, 春椎手術前に原発巣の治療を行っ ていたものは 13 例で, 脊椎手術後原発巣の治療を 7 例に開始した。 


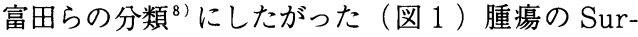
gical stage は, Stage 1) 2例, Stage 2) 6 例, Stage 3）8例, Stage 4）4例であった.

術前に両下肢のしびれ感, 痙性跛行を主症状とした 1 例を除き 19 例に疼痛を認め, また，各症例の神経 症状を Frankel らの分類に従うと, A：3例， B : 4 例, C : 4 例, D : 5 例, E : 4 例で, 神経症状を 16 例に認めた。膀胱直腸障害は, 調べ得た 18 例中 7 例に認めた。

手術方法は，前方・後方の除圧．固定術を one stage で行った 7 例（頝椎 2 例, 胸椎 3 例, 腰椎 3 例), two stage で行った 1 例（胸椎), 後方進入による除 圧固定術を 10 例（胸椎 7 例，腰椎 3 例）に，後方固 定術のみを 2 例（胸椎 2 例）に行い全例 instrumentation を使用した。また，術中出血の減少を目的と して術前に embolizationを 7 例に施行した。

\section{結果}

手術を行った 20 例中生存しているのは 10 例で, 10 例は, 術後平均 4.5 力月（1 カ月～ 8 力月）で死亡し た，原発巣別にみると，乳癌 7 例中 6 例と腎癌 4 例中 3 例, 悪性リンパ腫 2 例中 1 例が生存しており，ほか は全例死亡した（表 1 )。術前 19 例において, 疼痛を 認めたが，術後全例において軽減或いは消失を見た。

また，神経症状を有していた 16 例中，Aは 3 例と も不変で, B 4 例中 2 例に改善を 2 例は不変であっ た. Cは 4 例中 3 例に改善を認め 1 例は不変であった.

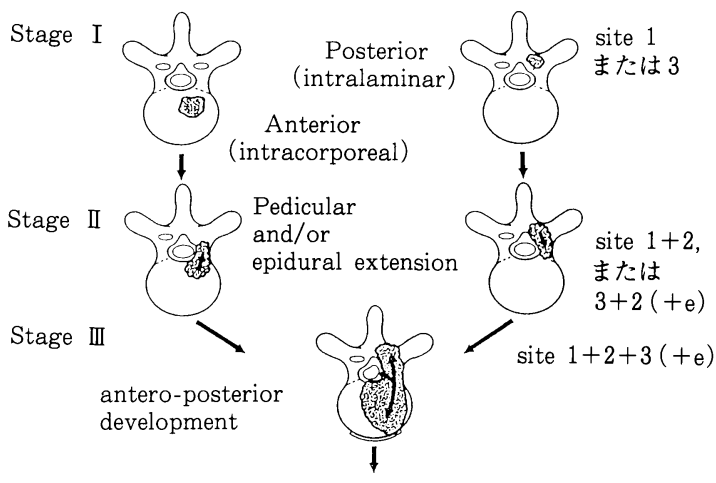

Stage IV

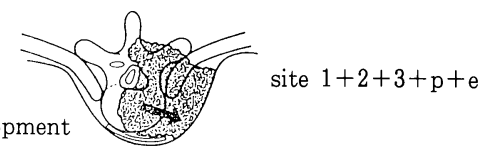

Paraspinal development

図 1 転移性脊椎腫瘍の surgical stage（Tomita）
$\mathrm{D}$ は 5 例中 2 例に改善を, 2 例は不変で 1 例に悪化を 認めた（表 2$)$ ．また，調べ得た範囲内で膀胱直腸障 害を有していた 7 例は, 術後も改善は認められなかっ た。

症例 1 ）腎臓癌 T11 の meta の症例である。疘性 跛行, 両下肢のしびれを主症状として当科初診, 単純 X線では, T11 It. pedicle sign と棘突起異常を認 め, MRIにて T11 の椎体, 棘突起に meta と cord の圧迫を認め CT では, 椎体, 椎弓根, 椎弓横突起, 棘突起に osteolytic な病変を認めた（図 2 ).ここの症 例に対し, まず後方からの除圧・固定を行い, 術中組 織より腎癌と判明し，二期的に前方除圧固定と腎摘出 を行った（図 3 ). 術後 2 年の現在全く再発を認めて いない.

症例 2 ) 乳癌の多発骨転移の 1 例である。背部痛 を主症状とし，単純 X 線にて T4 圧迫骨折，T9 It pedicle signを認め（図 4)，MRIにおいては，多 発性に脊椎転移を認め（図 5 ), 骨シンチでは, 脊椎 以外に, 肋骨, 骨盤, 左上腕, 大腿骨に集積像を認め た．本例に対して疼痛の軽隇を目的として T2-7の Hartshill rectangular rod にSLW を併用し固定

表 1 結 果

\begin{tabular}{|c|c|c|}
\hline & 生存中 & 死亡 \\
\hline 乳 腺 & 6 例 (2.5-16.5 力月) & 1 例 (2 力月) \\
\hline 腎 臓 & 3 例（2-18 力月） & 1 例 (8力月) \\
\hline 肝 · 胆道系 & 0 例 & 3 例 (1.5-6.5 力月) \\
\hline 消化管 & 0 例 & 2 例（6-11 力月） \\
\hline 前立腺 & 0 例 & 1 例（4 力月） \\
\hline リンパ系 & 1 例 (2.5 力月) & 1 例（1 カ月） \\
\hline 骨 髄 & 0 例 & 1 例（1.5 カ月） \\
\hline 計 & $\begin{array}{c}10 \text { 例 (2.5-18 力月) } \\
\text { (平均 } 7.1 \text { 力月) }\end{array}$ & $\begin{array}{r}10 \text { 例 (1-8 力月) } \\
\text { (平均 } 4.5 \text { 力月) }\end{array}$ \\
\hline
\end{tabular}

表 2 神経症状の推移 (Frankel 分類)

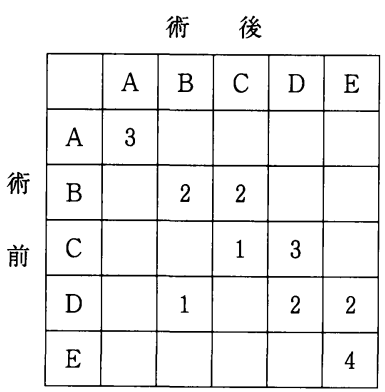


plain x-p） T11, It pedicle sign, 棘突起異常を認める.
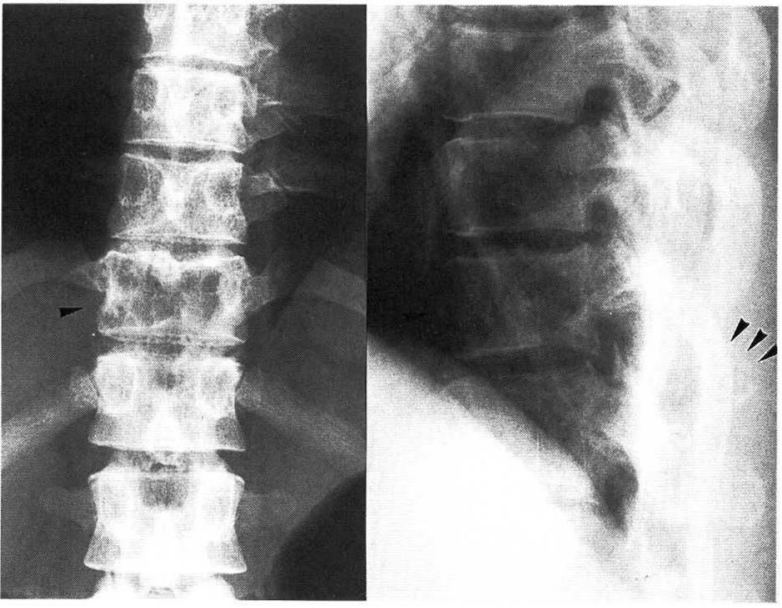

MRI） T11 椎体, 棘突起に転移病巣を認め, 同部位にて前後方向より cord の圧迫も 認める。

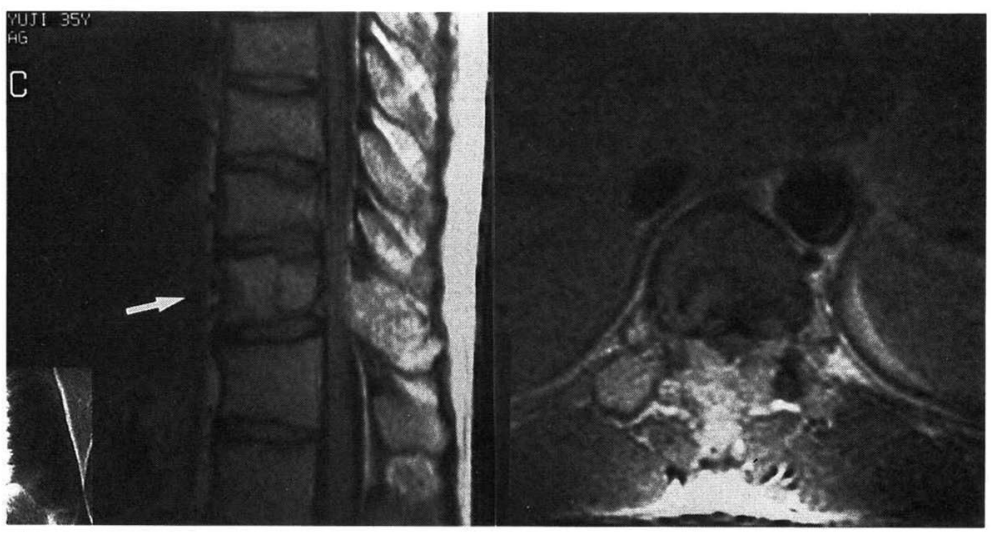

CT） T11 椎体, 椎弓根, 椎弓, 棘突起に osteo lytic な変化を認める.

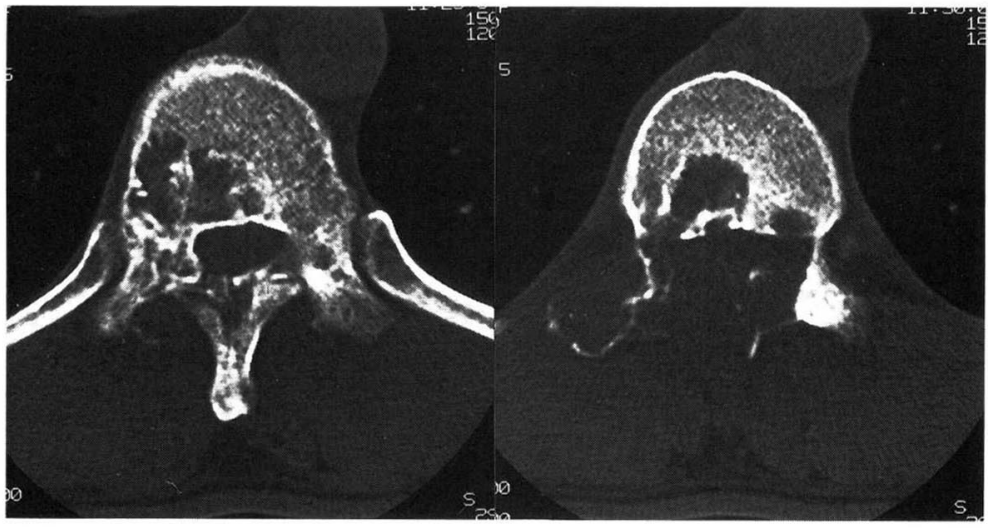

図 2 


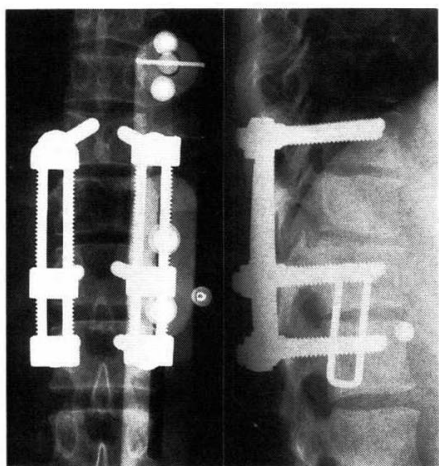

後方除圧固定術後

(T11 laminectomy +Simmonds PSS)
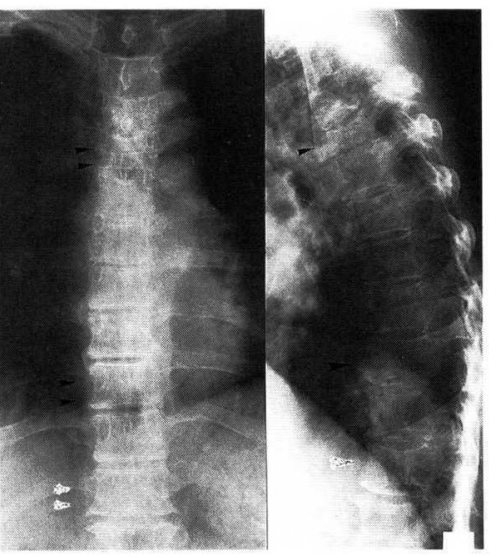

T4：圧迫骨折, T9 pedicle sign を認める

図 4

を行った（図 4 ). 術後 1.5 年経過しているが, 背部 痛は消失し, 神経症状は認められていない。経過中, 両大腿骨，両上腕骨に病的骨折をきたし髄内釬を挿入 した（図 6 ). 脊椎に対しては, 除痛を得られたが, 他の転移巣による症状のため QOL が低下している.

$$
\text { 考察 }
$$

悪性腫瘍の脊椎骨転移に対する手術適応は一般に 1) 全身状態が良好であり 2) 生命予後が $3 \sim 6$ カ 月以上期待でき 3 ) 重要臟器に転移を認めず 4) 転 移病巣が単発あるいは限局しており 5 ) 完全麻盘で はなく 6 ）保存的治療抵抗性の疼痛を有する場合と 延べられているが，われわれは，内山ら ${ }^{9)}$ 長島ら ${ }^{51}$ と 同様に 1 ）の全身状態が良好であることを最大の手術

図 3

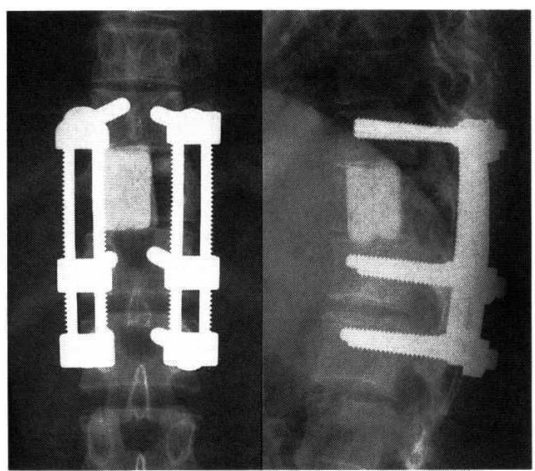

1 st ope + AIF 前方除圧固定も追加

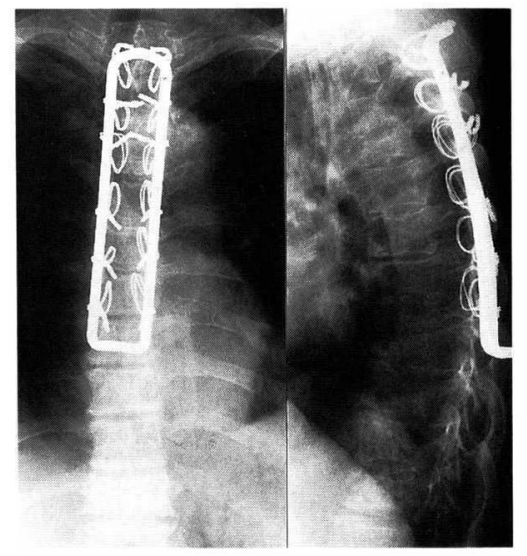

後方固定術後

( $\mathrm{T} 2-7$ rectangular rod $+\mathrm{SLW})$

適応とした。

具体的な術式は, 原発巣の性格, 転移病巣の surgical stage, 転移部位, 術前の神経症状を参考にし て決定した.

原発巣の性格

臨床的に比較的低悪性度で, 緩徐な進行をする乳癌 や，原発巣の完全摘出により根治性の認められる腎癌 においては, 転移病巣の可及的掻爬, 脊髄の除圧, 強 固な内固定を行い併用療法として全身性に化学療法や 免疫療法を, また, 感受性があるならばホルモン療法 を行い転移巣の局所的根絶を目指し, 転移巣が, 多椎 間にわたっている場合, 腫場の局所的根絶は難しく, 今回の結果からも乳癌 7 例中 5 例は転移巣が多椎間に わたり，また脊椎骨以外の長管骨にも転移を認め，そ 


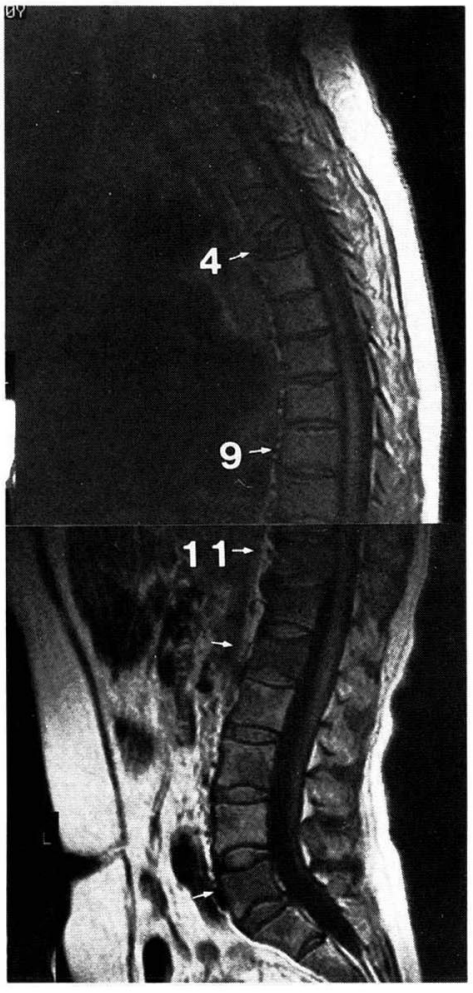

MRI
T1 W.I.

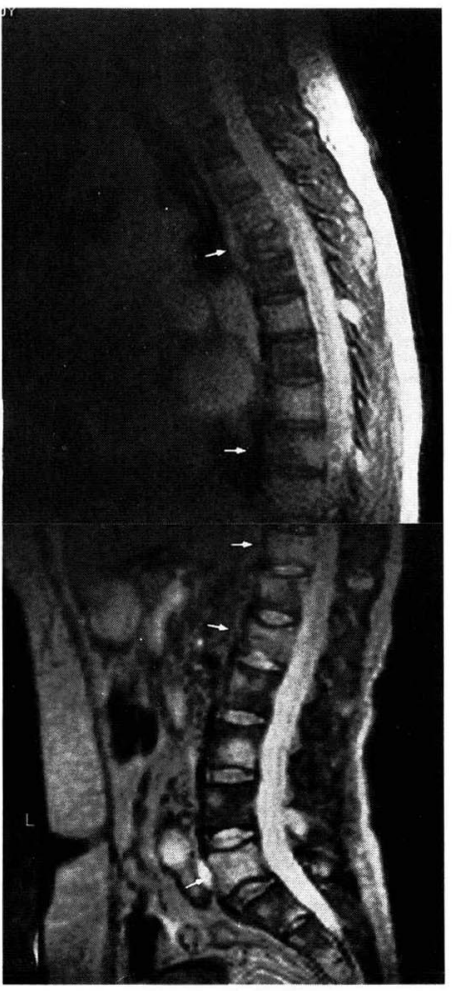

T2 W.I.

図 5 多発性に脊椎転移を認める.

の部分に由来する疼痛や病的骨折を生じ QOL は低下 している。転移巣の拡大する前に治療を行っていれば より高い効果が望めたのかも知れない. 一方で臨床的 に高悪性度で, 急速な進行をする肝, 胆道系, 消化器 系の腫瘍は, 脊椎に転移を認めた時点でほかの重要臓 器に転移を起こしている可能性が高く, 局所の根治性 を求めるよりは, 侵襲を出来るだけ少なくし, 固定術 を中心とした姑息的手術を行う。

転移病巣の進展程度

富田ら ${ }^{8)}$ の言う, Stage 1 (site 1) , Stage 2 (site 1+2), Stage 3 の場合, 術式は前方後方両側 進入の形をとる. Stage 1（site 1) の場合は, 前方 進入による除圧固定を行うと述べてある報告 ${ }^{1-4) 6 / 8) ~}$ が多いが, 残存腫瘍組織の後方進展による不安定性発 生の可能性, 椎体置換物の脱転に伴う後弯変形の予防 のためまず後方固定を行いその後に前方部分の処置を 行っている. Stage 1 (site 3), Stage 2（site 2+3） の場合は, 後方進入による除圧, 固定を行う. Stage
4 の場合は, 単なる固定のみか, 除圧, 固定を行う. 使用する instrument は, 下部頝椎, 澒胸移行部, 上 位胸椎の場合は, 佐々木ら ${ }^{7)}$ と同様に病巣部を中心と した上下 2 椎間を原則として主に rectangular rod を用い, 下部胸椎, 腰椎に対しては, 上下 1 椎間で transe pedicular screw を用いている。 また, 前方 は人工骨単独か自家骨の併用により椎体置換 ${ }^{1 / 3) 4) を ~}$ 行う.

以上述べた術式を個々の症例の病態に応じて選択し ている.

$$
\text { ま と め }
$$

乳癌, 腎癌の脊椎転移は比較的に予後良好で, 転移 单を含めた積極的手術の適応がある，特に乳癌では長 期生存が期待できる。 それに対し, 消化器由来のもの は一時的な QOL の改善しか得られず，手術的適応に 限界がある。 

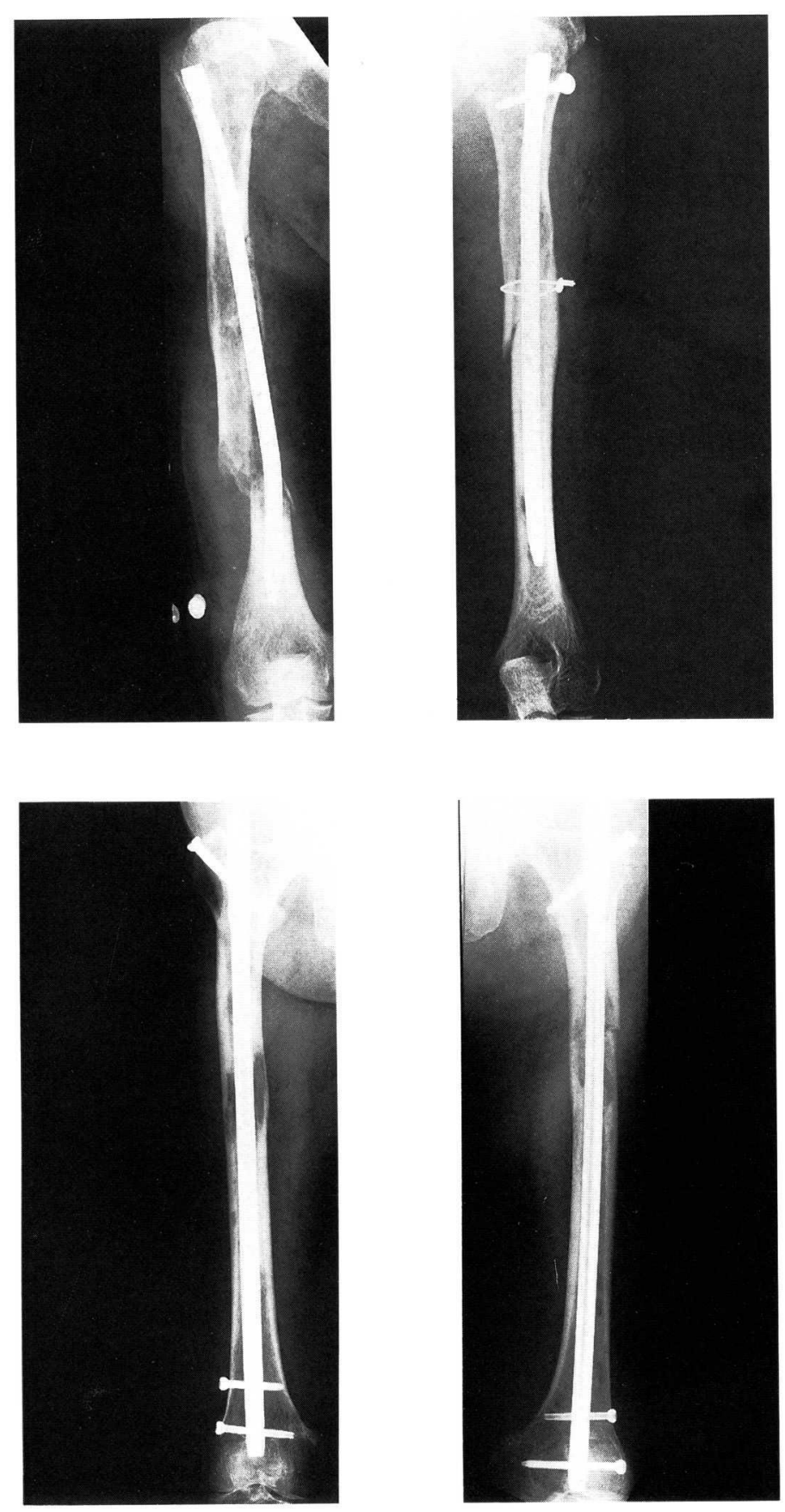

図 6 脊椎後方固定術後, 背部痛消失するも, 経過中に両大腿骨, 両上腕骨に骨転移による病的骨折をきたし髄内針を挿入した。 


\section{参考文 献}

1) Atanasiu, J.P. et al.: Metastatic Lesions of the Cervical Spine. SPINE, $18: 1279-1284,1993$.

2）川上 守ほか：転移性脊椎腫瘍の治療成績とその外科 的治療の適応. 臨整外, $25: 1195-1200,1990$.

3）真鍋昌平：骨転移；春椎転移に対する手術法の進歩. 癌と化学療法, $17: 785-790,1990$.

4) Manabe, S. et al.: Surgical Treatment of Metastatic Tumors of the Spine. SPINE, $14: 41-47,1989$.

5）長島太郎ほか：転移性脊椎腫瘍に対する手術療法の除
痛効果. 東日本臨整会誌, $3: 647-653,1991$.

6) O'Neil, J. et al.: Treatment of Tumors of the Thoracic and Lumbar Spinal Column. Clinical Orthopaedics and Related Research, $227: 103-112,1988$.

7）佐々木邦雄ほか: 転移性脊椎腫瘍に対する手術的治療. 整形外科と災害外科, $39: 326-330,1990$.

8）富田勝郎ほか：転移性脊椎腫場の手術 ; 特に Posterior Total Spondylectomyを中心に. 臨整外, $27: 481-490$, 1992.

9）内山政二ほか：転移性脊椎腫場による対麻疸に対する 手術的療法. 整形外科, $42: 1301-1308,1991$. 